\title{
PEMETAAN SEBARAN TERUMBU KARANG MENGGUNAKAN CITRA SATELIT SPOT-6 DI PERAIRAN PULAU PARI KEPULAUAN SERIBU JAKARTA
}

\author{
The Disribution Mapping of Coral Reefs Using SPOT-6 Satelite in the Water of Pulau Pari \\ in Thousand Islands Jakarta
}

\section{Yonas Ramadhan Maulana, Supriharyono*, Sigit Febrianto}

Program Studi Manajemen Sumberdaya Perairan, Departemen Sumberdaya Akuatik

Fakultas Perikanan dan Ilmu Kelautan, Universitas Diponegoro

Jl. Prof. Soedarto, SH, Tembalang, Semarang, Jawa Tengah - 50275. Telp/Fax. +6224 7474698

Email : yonasrm@gmail.com

\begin{abstract}
ABSTRAK
Pulau Pari merupakan salah satu pulau dari gugusan Kepulauan Seribu, Jakarta yang memiliki ekosistem terumbu karang. Pencemaran minyak yang terjadi di Teluk Jakarta serta meningkatnya jumlah wisatawan di Pulau Pari memberikan dampak terhadap ekosistem terumbu karang di wilayah tersebut. Berdasarkan hal tersebut, maka diperlukan kajian mengenai kondisi terumbu karang di Pulau Pari, Kepulauan Seribu dan penyebab utama terjadinya degradasi pada terumbu karang tersebut. Penelitian ini menggunakan purposive sampling technique dan metode survei, materi yang digunakan pada penelitian ini adalah Citra Satelit SPOT-6 dan data hasil pengukuran terumbu karang di Pulau Pari, Kepulauan Seribu, Jakarta. Hasil penelitian menunjukkan bahwa suhu di tiap stasiun berkisar antara 27 $29^{\circ} \mathrm{C}$, salinitas 31-32\%, kekeruhan air masih dibawah ambang batas baku mutu kekeruhan air untuk biota laut yaitu $<0.1$ NTU. Persentase karang hidup di Pulau Pari ditinjau dari penutupan karang memiliki nilai yang beragam, nilai terendah $24.20 \%$ atau dapat dikatakan karang dalam kondisi rusak dan nilai tertinggi sebesar 41,64\%. Uji akurasi digunakan sebagai fiksasi hasil interpretasi citra dengan data di lapangan, dari 50 titik sampling di lapangan terdapat 35 titik sampling yang sesuai dengan analisis penginderaan jauh pada citra SPOT-6. Titik sampling yang keliru menginterpretasikan penutupan lahan yaitu 15 titik sampling. Hal ini menunjukkan nilai akurasi dari penggunaan citra SPOT-6yaitu sebesar 70.00\%. Hasil yang didapat hasil klasifikasi citra maupun sampel training area menunjukan kemampuan yang baik dan dapat digunakan dalam proses pemetaan.
\end{abstract}

Kata kunci : Pulau Pari; Terumbu karang; Citra SPOT-6

\begin{abstract}
Pari Island is one of the thousand islands knows has a luxury coral reef's ecosystem. Oil pollution in Jakarta bay and the increasing number of tourists on the Pari Island had an impact on coral reef ecosystems these activities may effect on degradation coral reefs in Pari Island. This theory used survey method and purposive sampling technique, the material used in this research is satellite SPOT-6 image and coral reef measurement data on Pari Island, Thousand Islands, Jakarta. The results of this study indicate that the temperature at each station ranged from $27-29^{\circ} \mathrm{C}$, salinity $31-32 \%$, turbidity of water is still below the standard threshold of water turbidity for marine biota, is $<0.1$ NTU. Live coral percentage on Pari Island viewed from coral cover has diverse value, the lowest value 24,20\% or can be said coral in damaged condition and highest value 41,46\%. The accuracy test is used as a fixation of the results of the interpretation of the image with the field data, from the 50 sampling points in the field there are 35 sampling points corresponding to the remote sensing analysis on the SPOT - 6. Sampling point mistakenly interpreting the land closure of 15 sampling points. It shows the accuracy value of the use of SPOT - 6 that is 70\%. The results obtained from the classification of image and sample training area shows a good ability and can be used in the mapping process.
\end{abstract}

\section{Keywords : Pari Island; Coral reffs; Citra SPOT-6}

\section{*) Penulis Penanggung Jawab}

\section{PENDAHULUAN}

Coral Triangle adalah wilayah di Indo-Pasifik yang ditetapkan berdasarkan pada kriteria bahwa adanya penemuan lebih dari 500 jenis karang di dalam wilayah perairannya. Kawasan Segitiga Terumbu Karang merupakan jantung terumbu karang dunia yang membentang di perairan laut Indonesia, Malaysia, Papua Nugini, Filipina, Kepulauan Solomon, dan Timor-Lestle (http://nccctiindonesia.kkp.go.id, 2018). Menurut Burke et al,. (2012), kawasan ini sering disebut dengan "Amazon Laut" mencangkup hampir 30\% luas terumbu karang dunia dan 75\% dari semua spesies karang yang dikenal namun, sumberdaya yang tidak ternilai tersebut sedang terancam. Penangkapan berlebih, penangkapan yang merusak, pembangunan pesisir, dan pencemaran mengancam lebih dari $85 \%$ luas terumbu karang di kawasan Segitiga Terumbu Karang tersebut. 
Pulau Pari merupakan salah satu pulau dari gugusan Kepulauan Seribu Jakarta yang memiliki ekosistem terumbu karang. Meningkatnya jumlah wisatawan di Pulau Pari menyebabkan tekanan terhadap terumbu karang selain itu, kasus pencemaran yang sering terjadi di kawasan Teluk Jakarta yang merupakan tempat bermuaranya 19 sungai yang berasal dari daratan Jakarta. Kasus pencemaran minyak yang terjadi di Teluk Jakarta pada penghujung tahun 2008, telah menyebabkan wilayah perairan Pulau Pari sebagai wilayah yang terkena dampak paling besar dari pencemaran yang terjadi (Nugraha et al., 2010).

Pulau Pari termasuk dalam kawasan Taman Nasional Kepulauan Seribu, Pulau Pari memiliki zona perumahan pulau di wilayah pulau, zona terbuka hijau budidaya di wilayah pulau serta zona pemerintahan daerah. Berdasarkan hal tersebut, maka diperlukan kajian. Pari Kepulauan Seribu dan penyebab utama terjadinya degradasi pada terumbu karang tersebut.

Tujuan Penelitian

1. Mengetahui Kondisi Terumbu Karang di kawasan perairan Pulau Pari Kepulauan Seribu, Jakarta.

2. Mengetahui kemampuan Citra Satelit SPOT-6 untuk memetakan tutupan terumbu karang di kawasan perairan Pulau Pari Kepulauan Seribu, Jakarta.

\section{MATERI DAN METODE PENELITIAN}

\section{A. Materi Penelitian}

Materi yang digunakan pada penelitian ini adalah Citra Satelit SPOT-6 dan data hasil pengukuran terumbu karang di Pulau Pari Kepulauan Seribu, Jakarta. Alat dan bahan yang digunakan dalam penelitian terdiri dari rol meter, alat snorkel, secchi disk, termometer, refraktometer, papan data, kamera underwater, GPS, software Er Mapper 7.0, Software Arc GIS 10.2.2, Microsoft Office 2010 Bahan yang digunakan terdiri dari citra satelit SPOT-6 sumber LAPAN (Lembaga Penerbangan dan Antariksa Nasional), peta rupa bumi Indonesia, serta pengamatan habitat terumbu karang secara lansung.

\section{B. Metode Penelitian}

\section{Waktu dan Tempat Penelitian}

Penelitian ini dilaksanakan di Pulau Pari Kepulauan Seribu, Jakarta pada Tanggal 18-25 Desember 2017. Penelitian didasarkan kepada metode survei dan menggunaakan purposive sampling technique sebagai metode pengambilan sampel, adapun pertimbangan penentuan stasiun pengambilan sampel yaitu dapat mewakili keadaan keseluruhan atau karakteristik dari wilayah setempat.

\section{Prosedur pengumpulan data karang}

Pengambilan data dilakukan dengan metode LT (Line Transect), metode ini merupakan teknik yang dikembangkan dalam ekologi tumbuhan terestrial dan diterapkan dalam ekologi terumbu karang. Metode LT (Line Transect) ini digunakan untuk mengestimasi penutupan objek atau kumpulan objek (dalam hal ini karang) yang ada di area tertentu dengan cara menghitung panjang bagian yang dilalui transek. Penelitian dilakukan pada tujuh lokasi.

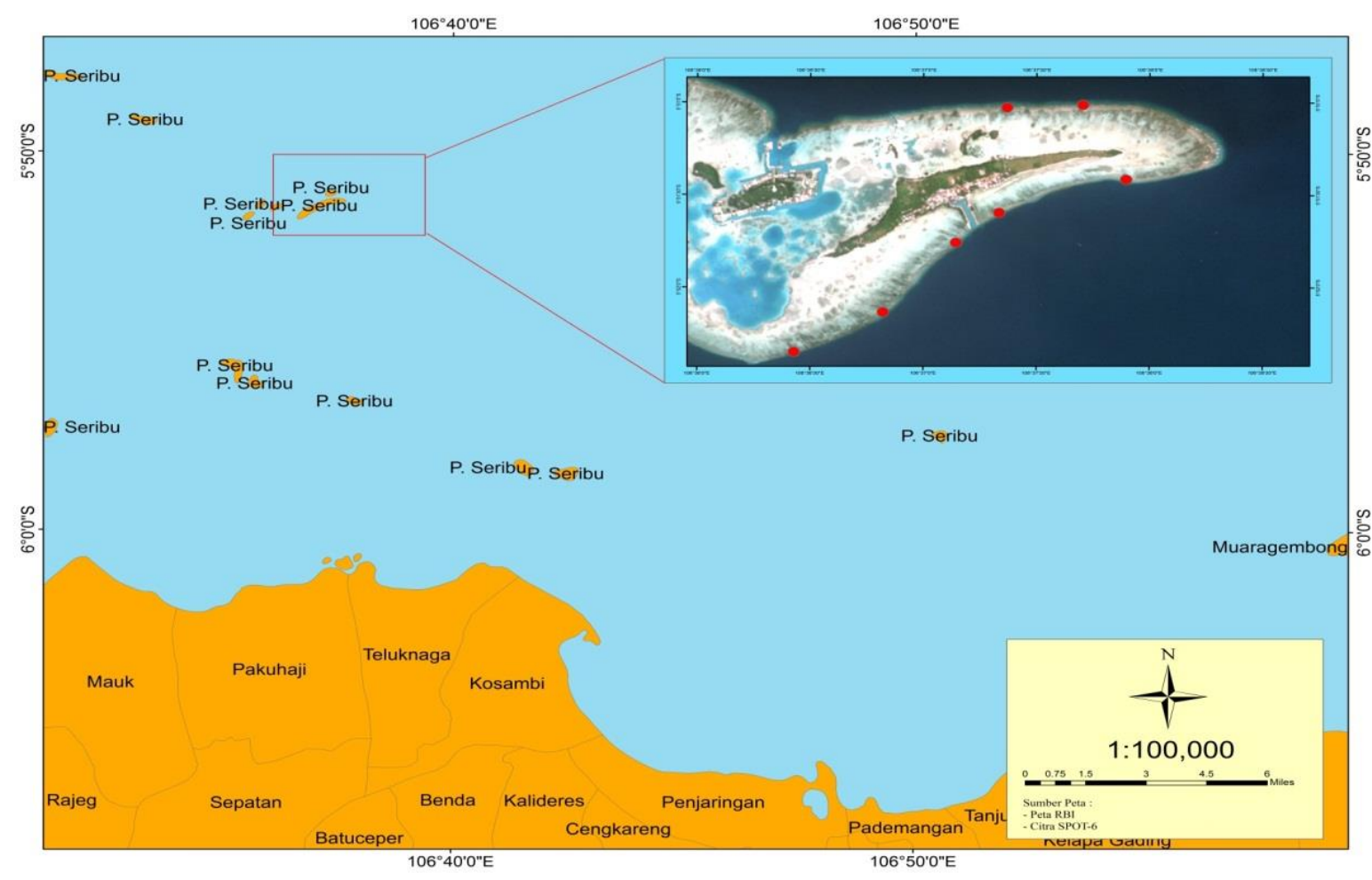

Gambar 1. Peta Lokasi Penelitian 
Tabel 1. Koordinat Titik Sampling

\begin{tabular}{ccc}
\hline \multirow{2}{*}{ Stasiun } & \multicolumn{2}{c}{ Koordinat } \\
\cline { 2 - 3 } & Bujur Timur & Lintang Selatan \\
\hline $\mathbf{1}$ & $106^{\circ} 37^{\prime} 19,2^{\prime \prime} \mathrm{E}$ & $05^{\circ} 51^{\prime} 36,4^{\prime \prime} \mathrm{S}$ \\
$\mathbf{2}$ & $106^{\circ} 37^{\prime} 52,9^{\prime \prime} \mathrm{E}$ & $05^{\circ} 51^{\prime} 24,0 " \mathrm{~S}$ \\
$\mathbf{3}$ & $106^{\circ} 37^{\prime} 40,7^{\prime \prime} \mathrm{E}$ & $05^{\circ} 51^{\prime} 0,94 " \mathrm{~S}$ \\
$\mathbf{4}$ & $106^{\circ} 37^{\prime} 37,4^{\prime \prime} \mathrm{E}$ & $05^{\circ} 51^{\prime} 02,8^{\prime \prime} \mathrm{S}$ \\
$\mathbf{5}$ & $106^{\circ} 37^{\prime} 10,1^{\prime \prime} \mathrm{E}$ & $05^{\circ} 51^{\prime} 44,1$ "S \\
$\mathbf{6}$ & $106^{\circ} 36^{\prime} 55,1^{\prime \prime} \mathrm{E}$ & $05^{\circ} 52^{\prime} 1,46 " \mathrm{~S}$ \\
$\mathbf{7}$ & $106^{\circ} 36^{\prime} 29,6^{\prime \prime} \mathrm{E}$ & $05^{\circ} 52^{\prime} 20,2^{\prime \prime} \mathrm{S}$ \\
\hline
\end{tabular}

Sumber: Data penelitian 2018

Panjang line transect adalah $25 \mathrm{~m}$, diletakan sejajar garis pantai, transek yang digunakan di daerah rataan terumbu sebanyak 1 line di kedalaman 1-4 m. pengamatan dilakukan dengan cara mencatat karang hidup dan karang mati yang ditemukan sepanjang transek garis pada daerah rataan terumbu karang. Pengambilan gambar karang mengunakan kamera underwater.

\section{Pengolahan data citra (Lyzenga)}

Citra satelit yang digunakan pada penelitian ini yaitu citra SPOT-6 yang memiliki nilai resolusi spectral $6 \mathrm{~m}^{2}$. Citra yang digunakan yaitu tahun 2017. Helmi et al., (2011), untuk menguatkan respon spectral terumbu karang pada penelitian ini dipilih beberapa metode transformasi untuk terumbu karang, yaitu Transformasi Lyzenga Metode transformasi tersebut digunakan untuk menguatkan respon spectral terumbu karang dan membedakannya dengan substrat dasar periran yang lain. Koreksi kolom air (water column correction) dan transformasi Lyzenga dapat mereduksi pengaruh efek kedalaman. Pergerakan dan kekeruhan air, untuk meningkatkan perolehan informasi karakteristik dasar perairan dangkal. Transformasi Lyzenga dilakukan dengan menghilangkan efek kolom air. Menurut Lyzenga (1981), Persamaan yang digunakan untuk tranformasi Lyzenga sebagai berikut :

$$
\mathrm{Y}=(\text { in }(\text { kanal } 1)+[(\mathrm{ki} / \mathrm{kj})(\text { in }(\text { kanal } 2))]) \text {. }
$$

Dimana Y merupakan hasil algoritma Lyzenga, (in (kanal 1)) merupakan logaritma natural kanal biru, (ki/kj) merupakan nilai varian dan kovarian pada kalan biru dan hijau, (in (kanal 2)) merupakan logaritma natural kanal hijau. Dilakukan pada sampel area sebanyak 30 titik untuk mendapatkan nilai varian dan ovarian. Pengambilan titik dilakukan dengan titik yang berwarna substrat yang sama yang diduga merupakan terumbu karang (Hariyanto dan Lingga, 2016). Setelah mendapatkan hasil dilanjutkan dengan melakukan uji akurasi menggunakan metode confution matriks.

\section{HASIL DAN PEMBAHASAN}

A. HASIL

\section{Parameter Fisika dan Kimia Perairan}

Hasil pengamatan pada parameter fisika dan kimia di perairan Pulau Pari Kepulauan Seribu, Jakarta tersaji pada tabel.

Tabel 2. Pengukuran Parameter Fisika dan Kimia Perairan

\begin{tabular}{|c|c|c|c|c|c|c|c|c|c|c|}
\hline \multirow{2}{*}{ No } & \multirow{2}{*}{ Parameter } & \multicolumn{7}{|c|}{ Kisaran Hasil Pada Stasiun } & \multirow{2}{*}{$\begin{array}{c}\text { Faktor } \\
\text { Pembatas }\end{array}$} & \multirow{2}{*}{$\begin{array}{c}\text { Daftar } \\
\text { Pustaka }\end{array}$} \\
\hline & & 1 & 2 & 3 & 4 & 5 & 6 & 7 & & \\
\hline 1 & Suhu $\left({ }^{\circ} \mathrm{C}\right)$ & 29 & 27 & 29 & 28 & 29 & 27 & 27 & $28-30$ & $\begin{array}{l}\text { (Kepmen LH } \\
\text { No 51, 2004) }\end{array}$ \\
\hline 2 & $\begin{array}{l}\text { Kedalaman } \\
\text { (m) }\end{array}$ & 2,15 & 2,85 & 0,65 & 0,56 & 3,5 & 2,75 & 2,1 & $<20 \mathrm{~m}$ & $\begin{array}{l}\text { (Kepmen LH } \\
\text { No } 51,2004)\end{array}$ \\
\hline 3 & $\begin{array}{l}\text { Kecerahan } \\
\text { (m) }\end{array}$ & SD & $\mathrm{SD}$ & SD & $\mathrm{SD}$ & SD & SD & SD & - & \\
\hline 4 & $\begin{array}{c}\text { Salinitas } \\
(\% / 00)\end{array}$ & 31 & 31 & 32 & 32 & 32 & 31 & 31 & $23-35$ & $\begin{array}{l}\text { (Kepmen LH } \\
\text { No 51, 2004) }\end{array}$ \\
\hline 5 & $\begin{array}{l}\text { Kekeruhan } \\
\text { (NTU) }\end{array}$ & $<0,1$ & $<0,1$ & $<0,1$ & $<0,1$ & $<0,1$ & $<0,1$ & $<0,1$ & $<5$ & $\begin{array}{l}\text { (Kepmen LH } \\
\text { No 51, 2004) }\end{array}$ \\
\hline
\end{tabular}

Sumber: Data penelitian 2018

Pengukuran parameter fisika dan kimia di perairan Pulau Pari Kepulauan Seribu dilakukan pada setiap stasiun. Hasil pengukuran suhu yang diperoleh pada tiap stasiun adalah berkisar antara $27-29^{\circ} \mathrm{C}$. Menurut Januardi et al., (2016), Nilai suhu yang berbeda diakibatkan oleh perbedaan kedalaman dan cuaca yang berubah-ubah. Nilai suhu terlihat bahwa hasil pengukuran termasuk dalam nilai optimal pertumbuhan karang sesuai dengan Keputusan Menteri Lingkungan Hidup No.51, (2004), yang berkisar antara $28-30^{\circ} \mathrm{C}$.

Hasil pengukuran Salinitas yang diperoleh pada tiap stasiun berkisar antara 31-32\% Nilai salinitas pada titik sampling relatif baik dikarenakan lokasi Pulau Pari Kepulauan Seibu yang cukup jauh dari sumber air tawar. Menurut 
Romimohtarto dan Juwana (2009), Salinitas mempengaruhi kehidupan hewan karang karena adanya tekanan osmosis pada jaringan hidup. Salinitas optimum bagi kehidupan karang berkisar antara $30-35 \%$.

Hasil pengukuran kekeruhan air pada setiap stasiun masih dibawah ambang batas baku mutu kekeruhan air untuk biota laut yaitu <0.1 NTU dimana menurut Keputusan Menteri Lingkungan Hidup No.51 (2004), menetapkan baku mutu untuk kekeruhan air yang baik dalam pertumbuhan biota laut yaitu dibawah $<5$.

\section{Persentase Penutupan Karang}

Berdasarkan hasil penelitian diperoleh perhitungan penutupan karang di Pulau Pari Kepulauan Sebiru, Jakarta, disajikan dalam tabel berikut:

Tabel 3. Persentase Penutupan Karang di Pulau Pari Kepulauan Seribu Jakarta

\begin{tabular}{|c|c|c|c|c|c|c|c|c|c|}
\hline No & Jenis Tutupan & $\begin{array}{c}\text { Stasiun } \\
1 \\
\end{array}$ & $\begin{array}{c}\text { Stasiun } \\
2 \\
\end{array}$ & $\begin{array}{c}\text { Stasiun } \\
3 \\
\end{array}$ & $\begin{array}{c}\text { Stasiun } \\
4 \\
\end{array}$ & $\begin{array}{c}\text { Stasiun } \\
5 \\
\end{array}$ & $\begin{array}{c}\text { Stasiun } \\
6 \\
\end{array}$ & $\begin{array}{c}\text { Stasiun } \\
7 \\
\end{array}$ & $\begin{array}{l}\text { Rata- } \\
\text { Rata }\end{array}$ \\
\hline 1 & Karang Hidup & $24,20 \%$ & $32,24 \%$ & $28,92 \%$ & $26,84 \%$ & $30,00 \%$ & $35,84 \%$ & $41,64 \%$ & $31,38 \%$ \\
\hline 2 & Karang Mati & $69,84 \%$ & $56,56 \%$ & $47,20 \%$ & $33,12 \%$ & $52,24 \%$ & $53,08 \%$ & $50,48 \%$ & $51,79 \%$ \\
\hline 3 & OtherLife & $0 \%$ & $1,00 \%$ & $6,76 \%$ & $15,48 \%$ & $2,04 \%$ & $1,20 \%$ & $7,08 \%$ & $4,79 \%$ \\
\hline 4 & Pasir & $5,96 \%$ & $10 \%$ & $17,12 \%$ & $24,56 \%$ & $15,72 \%$ & $9,88 \%$ & $0,80 \%$ & $12,03 \%$ \\
\hline & Total & $100 \%$ & $100 \%$ & $100 \%$ & $100 \%$ & $100 \%$ & $100 \%$ & $100 \%$ & $100.00 \%$ \\
\hline
\end{tabular}

Sumber: Data penelitian 2018

Nilai persentase karang hidup di Pulau Pari, Kepulauan Seribu Jika dilihat dari penutupan karang disetiap stasiun memiliki nilai yang beragam. Nilai terendah dari persentase karang hidup terdapat pada stasiun 1 sebesar $24.20 \%$ atau dapat dikatakan karang dalam kondisi rusak. dimana lokasi ini memiliki kedalaman $2.15 \mathrm{~m}$ dan lokasi ini tidak jauh dari dermaga Pulau Pari. Sedangkan nilai tertinggi pada stasiun 7 sebesar 41,64\% atau dapat dikatakan karang dalam kondisi sedang, lokasi ini memiliki kedalaman $2.1 \mathrm{~m}$ dimana lokasi ini tidak banyak dilalui oleh perahu pariwisata dan nelayan. Menurut Rauf et al., (2015), dimana lokasi merupakan area perlindungan laut (APL) yang dikelola oleh Pusat Penelitian Oseanografi (P2O) LII yang secara rutin menjaga kelestarian ekosistem terumbu karang. Nilai rata-rata dari persentase karang hidup di Pulau Pari, Kepulauan Seribu yaitu sebesar 31.38\% atau dapat dikatakatan kondisi karang yaitu dalam kondisi Sedang. Menurut Keputusan Menteri Lingkungan Hidup No.4 (2001), Menyatakan bahwa presentase penutupan terumbu karang 25-49,9\% termasuk dalam kategori sedang.

\section{Komposisi Life Form Terumbu Karang}

Berdasarkan hasil penelitian dilakukan di Pulau Pari diperoleh hasil yang mendukung pertumbuhan dari terumbu karang disajikan di dalam tabel berikut:

Tabel 4. Komposisi Life Form Terumbu Karang di Pulau Pari Kepulauan Seribu Jakarta

\begin{tabular}{|c|c|c|c|c|c|c|c|c|c|}
\hline \multirow{2}{*}{$\begin{array}{c}\text { Life } \\
\text { Form }\end{array}$} & \multicolumn{8}{|c|}{ Persentase \% } & \multirow[b]{2}{*}{$\begin{array}{c}\text { Persentase } \\
\%\end{array}$} \\
\hline & $\begin{array}{c}\text { Stasiun } \\
1\end{array}$ & $\begin{array}{c}\text { Stasiun } \\
2\end{array}$ & $\begin{array}{c}\text { Stasiun } \\
\mathbf{3}\end{array}$ & $\begin{array}{c}\text { Stasiun } \\
4\end{array}$ & $\begin{array}{c}\text { Stasiun } \\
5\end{array}$ & $\begin{array}{c}\text { Stasiun } \\
6\end{array}$ & $\begin{array}{c}\text { Stasiun } \\
7\end{array}$ & jumlah & \\
\hline ACB & 7,60 & 8,88 & 10,20 & 12,24 & 5,00 & 4,80 & 13,68 & 62,40 & 28,40 \\
\hline ACD & 2,44 & 1,40 & 1,00 & 1,28 & 2,84 & 2,60 & 0,40 & 11,96 & 5,44 \\
\hline ACE & 0,60 & & & & & & & 0,60 & 0,27 \\
\hline ACS & & 1,00 & & 1,72 & 1,20 & 1,96 & 0,80 & 6,68 & 3,04 \\
\hline ACT & 1,60 & 3,52 & 0,40 & 0,80 & 2,84 & 2,20 & 1,04 & 12,40 & 5,64 \\
\hline CB & 2,80 & 2,00 & 3,20 & 2,40 & 0,60 & 1,00 & 6,20 & 18,20 & 8,28 \\
\hline $\mathbf{C F}$ & 5,68 & 6,08 & & & 3,60 & 6,48 & 13,40 & 35,24 & 16,04 \\
\hline CE & 0,60 & & & & 1,20 & 2,20 & 2,68 & 6,68 & 3,04 \\
\hline CS & 0,88 & 1,00 & 6,20 & 1,36 & 5,20 & 1,20 & 1,20 & 17,04 & 7,76 \\
\hline CHL & & & 2,72 & & & & & 2,72 & 1,24 \\
\hline CMR & & 1,12 & & & & 0,44 & & 1,56 & 0,71 \\
\hline CM & 2,00 & 7,24 & 5,20 & 7,04 & 7,52 & 12,96 & 2,24 & 44,20 & 20,12 \\
\hline Jumlah & 24,20 & 32,24 & 28,92 & 26,84 & 30,00 & 35,84 & 41,64 & 219,68 & 100,00 \\
\hline
\end{tabular}

Sumber: Data penelitian 2018

Hasil pengamatan bentuk pertumbuhan karang di Pulau Pari menunjukan bahwa didaerah tersebut didominasi oleh karang dengan bentuk pertumbuhan Acropora Branching dengan Persentase $28.40 \%$ dan diikuti dengan Coral Massive dengan Persentase $20.12 \%$ sedangkan persentase bentuk pertumbuhan terendah Acropora Encrusting dengan persentase 0.60\% dan Coral Mushroom dengan persentase 1.56\%. Menurut English et al., (1994) dalam Riska (2013), tipe karang branching merupakan tipe terumbu karang tepi yang bercabang banyak terdapat di sepanjang tepi terumbu dan bagian atas lereng, terutama yang terlindungi atau setengah terbuka.

\section{Luasan Terumbu Karang}

Berdasarkan pengolahan data citra satelit SPOT-6 tahun 2017 di Pulau Pari Kepulauan Seribu Jakarta, dan diklasifikasikan menjadi 6 kategori yaitu karang hidup, karang mati, pecahan karang, padang lamun, pasir, dan lautan. Pembagian kelas-kelas mengacu pada data lapangan lokasi penelitian. Pengolahan citra mengunakan tranformasi Lyzenga dengan softeware ermapper 7.0. Luasan tiap-tiap kelas yang didapat dalam pengolahan citra hasil klasifikasi yaitu luasan karang hidup sebesar 35.22 ha, Karang Hidup dan karang mati sebesar 49.20 ha, pecahan karang sebesar 107.47 ha, pasir dan lamun sebesar 236.19 ha, pasir sebesar 362.23 ha dan laut sebesar 2433.711 ha. 


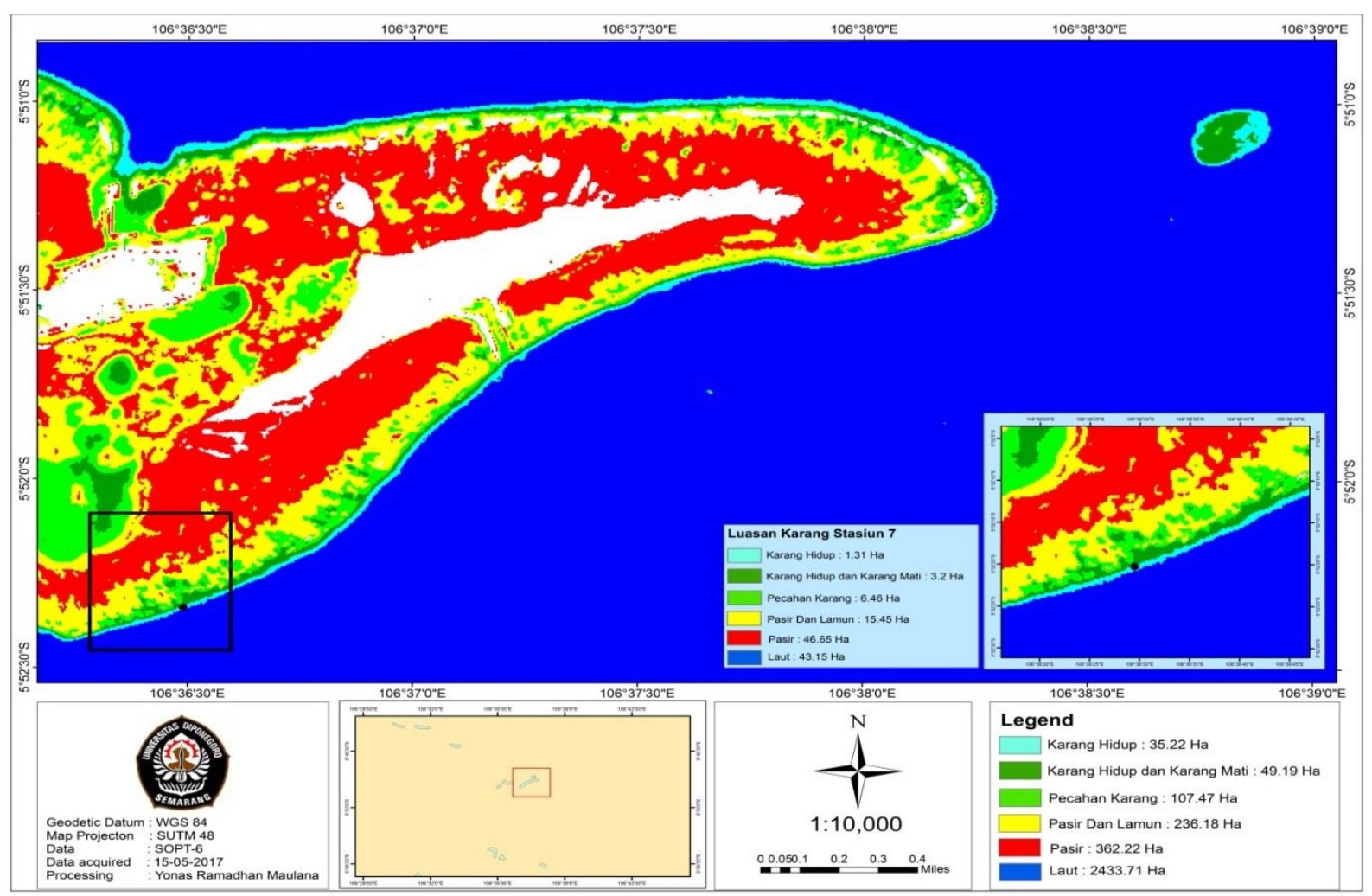

Gambar 2. Peta Hasil pengolahan citra SPOT-6

\section{Uji Akurasi Penutupan Lahan}

Berdasarkan pengamatan lokasi terumbu karang menyebar di seluruh bagian pulau namun masing - masing titik memiliki penutupan dan kondisi yang berbeda. Uji akurasi digunakan sebagai fiksasi hasil interpretasi citra dengan data di lapangan. didapat dari 50 titik sampling di lapangan, terdapat 35 titik sampling yang sesuai dengan analisis penginderaan jauh pada citra SPOT-6. Titik sampling yang keliru menginterpretasikan penutupan lahan yaitu 15 titik sampling. Hal ini menunjukkan nilai akurasi dari penggunaan citra SPOT-6yaitu sebesar $70.00 \%$. Hasil yang didapat hasil klasifikasi citra maupun sampel training area menunjukan kemampuan yang baik dan dapat digunakan dalam proses pemetaan. Menurut Grenn et al., (2000) dalam Wahidin (2014), Nilai akurasi pemetaan antara 60-80\% dapat direkomendasikan bagi kegiatan inventarisasi untuk pemantauan sumberdaya.

\section{B. PEMBAHASAN}

\section{Kondisi Karang}

Berdasarkan hasil penelitian menggunakan metode LT (Line Transec) persentase tutupan karang hidup terendah terdapat pada stasiun 1 yaitu $24.20 \%$ dimana pada stasiun ini didominasi bentuk pertumbuhan Acropora Brancing (ACB) dan Coral Foliose (CF) sedangkan bentuk pertumbuhan terendah oleh Acropora Encrusting (ACE). Stasiun 1 memiliki kedalaman $2.15 \mathrm{~m}$ dimana Lokasi ini tidak jauh dari dermaga Pulau Pari sehingga banyak perahu pariwisata dan nelayan menyebabkan banyak terdapat karang mati akibat dari aktivitas tersebut sehingga menjadi stasiun dengan tutupan karang hidup terendah masuk dalam kategori buruk. Sedangkan tutupan karang tertinggi terdapat pada stasiun 7 memiliki tutupan karang hidup sebesar $41.64 \%$ dimana pada stasiun ini didominasi oleh Acropora Brancing (ACB) dan Coral Foliose (CF)) sedangkan tutupan terendah oleh Acropora Digitate (ACD). Stasiun 7 memiliki kedalaman $2.1 \mathrm{~m}$ dengan tutupan karang hidup terbesar masuk dalam kategori sedang dan merupakan area perlindungan laut (APL) yang dikelola oleh Pusat Penelitian Oseanografi (P2O) LII yang secara rutin menjaga kelestarian ekosistem terumbu karang. Kedalaman memeiliki peran penting dalam pertumbuhan laju karang dimana kedalaman menentukan ketersediaan cahaya matahari yang mampu menembus badan perairan Menurut sulisyati et al., (2014), sesuai nilai baku mutu air laut nilai kecerahan untuk menunjang kehidupan karang adalah $>5 \mathrm{~m}$. kecerahan perairan berhubungan dengan ketersediaan intensitas cahaya matahari yang dapat digunakan oleh zooxanthellae untuk melangsungkan fotosintesis secara optimal sehinga mendukung pertumbukan karang. menurut Thovyan et al., (2017), Bahwa kedalaman memiliki hubungan yang tidak searah dengan persentase tutupan karang dimana jika kedalaman bertambah maka persentase tutupan karang akan berkurang. Kondisi ini juga terkait dengan zooxanthellae yang bersimbiosis dengan hewan karang. jika kedalaman bertambah maka penetrasi cahaya akan berkurang dan zooxanthellae tidak dapat melakukan fotosintesis. Menurut hasil penelitian Wahyudiono (2009), bahwa pengaruh pelabuhan terhadap kerentanan terumbu karang disebabkan oleh jangkar kapan dan baling-baling kapal yang berada pada dermaga selain itu tumpahan sisa minyak bahan bakar kapal juga berpengaruh terhadap kerentanan terumbu karang. 
Berdasasrkan hasil penutupan karang disetiap stasiun didapat tutupan rata-rata sebesar $31.38 \%$ karang hidup. Menurut Keputusan Menteri Lingkungan Hidup No.4, (2001), kategori tutupan karang memiliki 4 kategori, dan hasil dari pendataan tutupan karang yang dilakukan pada ketujuh stasiun tersebut termasuk dalam kategori sedang yaitu 25 49,9\%. Lebih lanjut berdasarkan hasil pelenilitian Yulius et al., (2015), Hasil penelitian menunjukan kondisi terumbu karang di perairan Pulau Wangi-Wangi masuk dalam kategori sedang hiingga baik. Persentase tutupan terumbu karang di lokasi pengamatan berkisar antara 28\%-60\%. Perairan pulau wangi wangi memiliki persentase pentutupan karang non-Acropora dan soft coral yang besar dibandingkan dengan yang lainnya. Menurut hasil penelitian Nugraha et al., (2010), Hasil pengamatan kondisi ekosistem terumbu karang di Pulau Pari menunjukan nilai persentase penutupan karang berada pada kisaran 21,46\%-70,82\% nilai tersebut menunjukan penutupan karang berada dalam kategori buruk hingga baik.

Komposisi Tutupan Life Form karang keras hidup didominasi oleh Acropora Branching, Coral Massive, dan Coral Foliose. Acropora Branching adalah tipe karang bercabang yang memiliki pertumbuhan cepat dengan perairan jernih dan banyak disepanjang tepi tertumbu dan lereng namun sangat rentan terhadap aktivitas penangkapan ikan dan sedimentasi. Coral Massive adalah pertumbuhan terumbu karang menyerupai bongkahan batu, Coral Massive banyak ditemukan pada periran dengan sedimentasi tinggi. Sedangkan Coral Foliose memiliki bentuk pertumbuhan lembaran lembaran yang memanjang dan menyerupai bunga biasanya dipengaruhi oleh arus dan kedalaman periran. Perairan dengan arus tenang sangat cocok bagi pertumbuhan karang jenis ini. Menurut Zamani (2015), Bentuk Karang yang banyak terdapat disepanjang tepi terumbu dan bagian atas lereng, terutama yang terlindungi atau setengah terbuka yaitu bentuk karang bercabang (Brenching) dan bentuk padat (Massive). Lebih lanjut menurut Suryanti et al., (2011), pada daerah dengan arus kuat banyak dijumpai karang berbentuk pendek, kuat merayap, submassif. Sementara pada daerah dengan arus yang lebih tenang banyak dijumpai karang berbentuk ramping memanjang.

Berdasarkan hasil penelitian membuktikan Pulau Pari termasuk dalam pulau yang memiliki nilai tutupan karang sedang dan harus lebih diperhatikan akan keberlangsungan hidup habitat dari ekosistem terumbu karang. Tinginya nilai tutupan karang mati menunjukan bahwa Pulau Pari pernah memiliki tutupan karang keras hidup yang tinggi. Kerusakan terumbu karang di perairan ini terutama diakibatkan oleh aktivitas manusia seperti kegiatan penelitian dimana kerusakan karang akibat terinjak yang menebabkan karang patah dan mati. serta pariwisata, pembangunan dan pembuangan limbah baik dari penduduk Pulau Pari maupun limbah dari wilayah Jakarta. Menurut hasil penelitian Renfro dan Chadwick (2017), Kegiatan pariwisata seperti snorkeling berdapak negatif terhadap terumbu karang. tingginya snorkeling rekreasi berdampak pada menurunnya tingkat tuutupan karang dan meningkatkan penutupan mikroalga. Menurut Tedesco et al., (2017), secara global, pariwisata yang tidak diatur dengan baik dianggap sebagai penyebab menurunnya pertumbuhan karang dan tingkat reproduksi. Lebih lanjut menurut Nugraha et al., (2010), Kasus pencemaran minyak yang terjadi di teluk Jakarta pada pengujung tahun 2008 menyebabkan wilayah di perairan Pulau Pari terkena dampak kerusakan pada terumbu karang.

\section{Parameter Fisika dan Kimia}

Kualitas perairan merupakan salah satu faktor yang mempengaruhi kondisi ekosistem terumbu karang dan biota yang hidup dan berlindung pada ekosistem tersebut. Parameter kualitas perairan yang memiliki peran penting antara lain suhu perairan, kecerahan, kedalaman, salinitas dan kekerurahan air.

Berdasarkan hasil penelitian diperoleh pengukuran parameter fisika yaitu suhu pada ketujuh stasiun memiliki nilai antara $27-29^{\circ} \mathrm{C}$. dimana nilai suhu tersebut termasuk dalam kategori baik. Keputusan Mentri Lingkungan Hidup No.51, (2004), kisaran suhu untuk perkembangan terumbu karang yaitu $28-30^{\circ} \mathrm{C}$. Menurut Mulyana (2006), suhu mempengaruhi kecepatan metabolisme, reproduksi dan perombakan bentuk dari karang. Suhu optimal bagi pertumbuhan karang berkisar antara $23^{\circ} \mathrm{C}-30^{\circ} \mathrm{C}$. Pada suhu di bawah $18^{\circ} \mathrm{C}$ dapat menghambat pertumbuhan karang bahkan dapat mengakibatkan kematian. Pada suhu diatas $33^{\circ} \mathrm{C}$ dapat menyebabkan gejala pemutihan (bleaching), yaitu keluarnya zooxanthella dari polip karang dan akibat selanjutnya dapat mematikan karang tersebut. suhu yang baik dalam akan mempengaruhi kondisi laju pertumbuhan karang. Menurut Rustam (2014), Perubahan suhu secara mendadak dapat menyebabkan karang mengalami stress dan mengeluarkan lendir yang juga dapat menyebabkan karang mati.

Salinitas merupakan jumlah total mineral terlarut yang terkandung di dalam satu kilogram air. Pertumbuhan karang dengan salinitas yang extrim dapat mengurangi laju pertumbuhan karang. Hasil penelitian pengukuran parameter salinitas sebagai faktor pembatas bagi karang didapatkan hasil $31 \quad-31 \%$ nilai salinitas tersebut termasuk dalam katergori baik. Menurut Romimohtarto dan Juwana (2009), salinitas mempengaruhi kehidupan hewan karang karena terdapat tekanan, salinitas optimum bagi kehidupan karang berkisar antara $30-35 \%$. Menurut pendapat Kordi (2010), salinitas yang sesuai untuk pertumbuhan karang adalah 27-35 ppt. Nilai salinitas perairan pulau pari masih baik untuk laju pertumbuhan biota laut.

Hasil pengukuran parameter kekeruhan air pada ketujuh stasiun didapatkan hasil sama yaitu <0.1 NTU dimana nilai tersebut masih berada dibawah baku mutu, dimana baku mutu kekeruhan air bagi pertumbuhan biota laut adalah $<5$ kategori tersebut termasuk dalam Keputusan Mentri Lingkungan Hidup No.51, (2004), baku mutu kekeruhan air yang baik bagi biota laut adalah $<5$. Kekeruhan merupakan Kekeruhan perairan merupakan keadaan terbalik dari kecerahan perairan. Kekeruhan perairan atau yang biasa disebut dengan turbiditas perairan merupakan suatu keadaan perairan disaat semua zat padat berupa pasir, lumpur dan tanah liat atau partikel-partikel tersuspensi dalam air dan dapat berupa komponen hidup (biotik) seperti fitoplankton (Edward dan Tarigan, 2003). Kondisi kekeruhan air pada perairain Pulau Pari masih baik untuk pertembuhan laju biota laut karena masih dibawah dalam ambang batas baku mutu biota laut. 
Semua parameter fisika kimia dibutuhkan dalam penelitian untuk mengetahui kondisi perairan. Kondisi perairan yang tidak baik dapat berdampak buruk terhadap organisme yang terdapat di dalamnya. Terumbu karang merupakan biota laut yang berdampak terhadap perubahan linhkungan. Menurut Edrus et al., (2013), menyatakan bahwa perubahan kondisi perairan dapat secara langsung atau tidak langsung berpengaruh terhadap tutupan karang. perubahan kondisi tutupan karang.

\section{Pemetaan Terumbu Karang dengan Citra SPOT-6}

Hasil pengolahan Citra SPOT-6 dengan software Ermapper mengunakan algoritma Lyzenga yang kemudian pembagian objek dengan kategori 6 kelas yaitu karang hidup, Karang mati, Pecahan Karang, Lamun, pasir dan laut. Wilayah yang tidak diikutsertakan yaitu daratan dalam pengklasifikasian. Data yang digunakan yaitu data Citra SPOT-6 tahun 2017.

Hasil luasan tiap-tiap kelas yang didapat dalam pengolahan citra hasil klasifikasi yaitu luasan karang hidup sebesar 35.22 ha, karang mati sebesar 49.20 ha, pecahan karang sebesar 107.47 ha, pasir dan lamun sebesar 236.19 ha, pasir sebesar 362.23 ha dan laut sebesar 2433.711 ha. Pada stasiun 7 memiliki penutupan karang tertinggi dengan $41.46 \%$ dengan luasan karang hidup seluas 1.31 ha. Berdasarkan hasil seluruh luasan karang hidup memiliki luasan yang paling rendah dibandingkan karang mati dan pecahan karang diperairan Pulau Pari. Menurut hasil penelitian Hapasri et al., (2017), hasil luasan terumbu karang pada kepulauan seribu yaitu sebesar $1.41 \mathrm{~km}^{2}$, kondisi terumbu karang pada 4 stasiun memiliki nilai penutupan $16.31 \%-50.42 \%$ hal tersebut menunjukan kondisi terumbu karang pada kepulauan seribu masuk dalam kategori rusak hingga baik. Lebih lanjut menurut hasil penelitian Arief (2012), hasil penelitian untuk mendeteksi terumbu karang menggunakan aplikasi data satelit SPOT-4 di Pulau Pari didapatkan hasil klasifikasi objek dasar perairan Pulau Pari terdiri dari 5 kelas yaitu karang yang muncul di permukanaan laut seluas 15.2 ha, karang yang bercampur dengan pasir seluas 230.06 ha, karang bercampur dengan pasir dan lamun seluas 220.8 ha, dan karang yang termasuk jenis karang penghalang (barrier reef) seluas 245.24 ha. Menurut hasil penelitian Mataburu (2015), hasil pengolahan data citra satelit Landsat 8 dengan persamaan Lyzenga dan hasil koreksi melalui pengamatan lapangan total luas terumbu karang di wilayah penelitian sebesar 1.025.014 ha dengan persentase terumbu karang dengan kondisi baik mencapai $91.84 \%$ dan kondisi rusak mencapai 8.16\%.

Hasil uji akurasi Citra SPOT-6 dengan mengunakan uji confution matriks didapatkan nilai sebesar 70.00\%. Pada pengolahan citra ini keakuratan dari pengolahan citra satelit dilakukan dengan hasil uji akurasi dari 50 titik yang diambil terdapat 15 titik yang tidak sesuai akibat kesalahan dalam citra satelit menginterpretasikan data. Pada pengujian akurasi ini terdapat yang namanya komisi dan omisi. Lebih lanjut menurut Januardi et al., (2016), pada citra satelit Landsat 8 dengan komposite warna true colour sulit untuk membedakan daerah yang ditafirkan, akurasi pada hasil pengolahan citra satelit Landsat 8 di Pulau Menjangan Besar didapat dari 48 titik yang dibuktikan di lapangan 39 titik yang sesuai denga citra satelit, namun 9 titik yang tidak sesuai akibat salahnya citra satelit dalam menginterpretasi data. Menurut Damayanti (2012), omisi merupakan jumlah piksel yang masuk kekelas lain sedangkan komisi adalah jumlah piksel masuk dari kelas lain. Nilai omisi tertinggi ada pada klasifikasi pasir, hal tersebut menunjukan bahwa pada hasil algoritma Lyzenga sulit menginterpretasikan antara pasir dengan habitat lainnya. Kesalahan tertinggi salah interpretasi antara lamun dengan pasir.

Dalam penelitian ini didapatkan nilai uji akurasi sebesar 70.00\%. menurut hasil penelitian Hapsari et al., (2017), Hasil uji akurasi yang didapatkan pada hasil interpretasi citra Landsat yaitu sebesar 69,37\%. Lebih lanjut menurut Damayanti (2012), ada beberapa literatur yang menyebutkan uji akurasi bisa dikatakan mewakili apabila nilainya minimal $80 \%$. Merujuk dari hal ini uji akurasi yang didapatkan bisa dikatakan juga memadai.

\section{KESIMPULAN DAN SARAN}

\section{Kesimpulan}

1. Kondisi terumbu karang di Pulau Pari termasuk dalam kategori buruk hingga sedang dengan tutupan karang 24.20\% - 41.64\%. dengan luasan terumbu karang sebesar 35.22 ha. Life form terumbu karang yang terdapat di Pulau Pari yaitu Acropora Branching, Acropora Submassive, Acropora Encrusting, Acropora Digitate, Acropora Tabulate, Coral Branching, Coral Encrusting, Coral Foliose, Coral Massive, Coral Submassive, Coral Mushroom dan Coral Helliopora.

2. Berdasarkan transformasi lyzenga dan pengklasifikasan didapatkan luasan habitat terumbu karang yang berkurang sebesar 35.22 Ha. Uji akurasi yang dihasilkan sebesar $70.00 \%$, hal ini mengartikan bahwa pemetaan terumbu karang menggunakan citra SPOT-6 dapat digunakan untuk memetakan terumbu karang dengan cukup baik.

3. Kemampuan resolusi citra berpengaruh terhadap pemetaan sebaran terumbu karang.

\section{UCAPAN TERIMA KASIH}

Penulis mengucapkan terima kasih kepada Prof. Norma Afiati, M.Sc., PhD dan Dr. Ir. Pujiono Wahyu P. MS selaku dosen penguji yang telah memberikan masukan dan saran serta PUSTEKDATA LAPAN yang telah memberikan data Citra Satelit SPOT-6 dan UPT LPKDSMO yang telah memberiakan layanan fasilitas. Terima kasih pula penulis ucapkan kepada pihak-pihak yang telah membantu dalam penyusunan penelitian. 


\section{DAFTAR PUSTAKA}

Arief, M. 2012. Aplikasi Data Satelit SPOT-4 untuk Mendeteksi Terumbu Karang: Studi Kasus di Pulau Pari. LAPAN, Jakarta. 14(1): 1-6

Burke, L. Reytar, K. Spalding, M. dan Perry, A. 2012. Menengok Kembali Terumbu Karang yang Terancam di Segitiga Terumbu Karang. World Resources Institute. 1(1): 24-32

Damayanti, Reina. 2012. Pemetaan Terumbu Karang di Perairan Pulau Tabuhan Kab. Banyuwangi Menggunakan Citra Satelit Quickbird. Program Studi Ilmu Kelautan Trunojoyo. Madura.

Edrus, I. N., S. W. Wijaya dan I. E. Setyawan. 2013. Struktur Komunitas Ikan Karang di Perairan Pulau Raya, Pulau Rusa, Pulau Rondo dan Taman Laut Rinoi Dan Rubiah, Nanggroe Aceh Darussalam, J. Lit. Perikan. Ind. 4: $175-186$

Edward dan Tarigan, Z. 2003. Pemantauan Kondisi Hidrologi di Perairan Raha P. Muna Sulawesi Tenggara dalam Kaitannya dengan Kondisi Terumbu Karang. Jurnal Makara Sains. 7(2): 73-82

Hapsari, R.A. Wijaya, N.I. dan Winarso, G. 2017. Luasan dan Sebaran Kondisi Terumbu Karang di Perairan Kepulauan Seribu. Fakultas Teknik dan Ilmu Kelautan Universitas Hang Tuah, B: 66-73

Hariyanto, T dan A. Lingga. 2016. Analisa Perubahan Luasan Terumbu Karang Dengan Metode Penginderaan Jauh (studi kasus: Pulau Menjangan, Bali). GEOID, 1(2): 171-175

Helmi,M, A. Hartoko, S. Herkiki, Munasik dan S. Wouthuyze. 2011, „Analisis respon spektral dan ekstraksi nilai spektral terumbu karang pada citra digital multispektral satelit ALOS-AVNIR di perairan gugus Pulau Pari, Kepulauan Seribu, Jakarta" Buletin Oseanografi Marina. 1:120-136.

Januardi, R. Hartoko, A. dan Purnomo P.W. 2016. Analisis Habitat dan Perubahan Luasan Terumbu Karang di Pulau Menjangan Besar Kepulauan KarimunJawa Mengunakan Citra Satelit. Journal Of Maquares Managemen Of Aquatic Resources. 5(4): 302-312

KEPMENLH. 2001. Lampiran Keputusan MENLH No. 04 tahun 2001 tentang : Kriteria Baku Kerusakan Terumbu Karang, Jakarta

KEPMENLH. 2004. Lampiran Surat Keputusan Mentri Negara Lingkungan No. 51 tahun 2004 tentang : Baku Mutu Air Laut Unttuk Biota Laut, Jakarta

Kordi, K.M.G.H. 2010. Ekosistem terumbu karang. Rineka Cipta. Jakarta. 212 hlm.

Lyzenga David R., 1981. Remote Sensing of Bottom Reflectance and Water Attenuation Parameters in Shallow Water Using Aircraft and Landsat Data. International Journal of Remote Sensing (IJRS). 2(1): 71-82.

Manullang, J. C. Hartoni dan H, Surbaki. 2014. Analisis Perubahan Luasan Terumbu Karang denagan Menggunakan Data Pengindaraan Jauh di Perairan Pulau Pramuka Kabupaten Administratif Kepulauan Seribu. Maspari journal. 6(2): 124-132

Mataburu, I. B. 2015. Identifikasi Kondisi Terumbu Karang Perairan Bagian Selatan Pulau Sepanjang, Kabupaten Banten Sumenep Dengan Mengunakan Citra Landsat 8. SPATIAL wahana Komunikasi dan Informasi Geografi. 13(1) : 14-21

Mulyana, Y. 2006. Pedoman Pelaksanaan Transplantasi Karang. Direktorak Jenderal Kelautan, pesisir dan Pulau-Pulau Kecil. Departemen Kelautan dan Perikanan. Jakarta

Nugraha, A. H, A. A. Mustika, G. S. J. Wijaya dan D. Adrian. 2010. Kondisi Ekosistem Terumbu Karang di Perairan Pulau Pari Kepulauan Seribu.

Rauf KP, Supriharyono, Purnomo PW. 2015. Kelimpahan Zooxanthellae pada Acropora sp. Berdasarkan kedalaman perairan dan naungan yang berada di Pulau Pari Kepulauan Seribu Jakarta. Diponegoro J Maquares Management of Aquatic Resources. (4)1: 46-54.

Renfro, B. dan Chadwick, N.E. 2017. Benthic Community Structure On Coral Reefs Exposed To Intensive Recreational Snorkeling. Research Ariticel

Riska. Sadarun, B.dan Yasir Haya, L.O.M. Kelimpahan Drupella pada Perairan Terumbu Karang di Pulau Belan-Belan Besar Selat Tiworo Kabupaten Muna, Sulawesi Tenggara. Jurnal Mina Laut Indonesia. 02(6): 69-80.

Romimohtarto, K dan S. Juwana. 2009. Biologi Laut Ilmu Pengetahuan tentang Biota Laut. Djambatan. Jakarta.

Rustam, A., Yulius, M. Ramdhan, H.L. Sa-lim, D. Purbani, dan T. Arifin. 2014. Analisis kualitas perairan kaitannya dengan keberlanjutan ekosistem un-tuk kawasan budidaya perikanan di kawasan pulau Wangi-wangi, Kabupaten Wakatobi, Dalam: Prosiding PIT ISOI-X, Ikatan sarjana oseanolo-gi Indonesia. Jakarta. Hlm.:91-104.

Suryanti, Supriharyono, Roslinawati Y. 2011. Pengaruh kedalaman terhadap morfologi karang di Pulau Cemara Kecil Taman Nasional Karimun Jawa. J Saintek Perikanan. 7(1):63-69.

Sulisyati, R. Poedjirahajoe, E. WF. Rahayu, L. dan Fandeli. 2014. Karakteristik Terumbu Karang di Zona Pemanfaatan Wisata Taman Nasional Karimun Jawa. Ilmu Kelautan.19(3): 139-148 
Tedesco, E.C, Segal, B. Calderon, E.N.dan Schiavetti, A. 2017. Consevation Of Brazilian Coral Reef In The Southwest Atlantic Ocean: A Change Of Approach. Latin American Journal Of Aquatic Research. Res 45(2): 228-245

Thovyan, A.I. Sabariah, V.dan Paranden, D. 2017. Persentase Tutupan Terumbu Karang di Perairan Pasir Putih Kabupaten Manokwari. Jurnal Sumberdaya Akuatik Indopasifik.1(1):67-80

United Nation Environment Protection, 1993. Penagamatan Terumbu karang dalam perubahan. Ilmu Kelautan. Australia.

Wahidin N, Siregar VP, Nababan B, Jaya I, Wouthuyzen S. 2014. Deteksi Perubahan Habitat Terumbu Karang Menggunakan Citra Landsat di Pulau Morotai Provinsi Maluku Utara. Jurnal Ilmu dan Teknologi KelautanTropis, Vol. 6, No. 2, Hlm. 507-524, Desember 2014. @Ikatan Sarjana Oseanologi Indonesia dan Departemen Ilmu dan Teknologi Kelautan, FPIK-IPB 507.

Wahyudiono. 2009. Kerentanan Terumbu Karang Akibat Aktivitas Manusia Mengunakan "Cell-Based Modelling” di Pulau Karimun Jawa dan Pulau Kemujan, Jepara, Jawa tengah.

Yulius. Novianti, N. Arifin, T. Salim, H.L. Ramadhan, M. dan Purbani, D. 2015. Distribusi Spasial Terumbu Karang di Periran Pulau Wangi-Wangi, Wakatobi. Jurnal Ilmu dan Teknologi Kelautan Tropis. 7(1): 59-69

Zamani NP. 2015. Kelimpahan Acanthaster planci sebagai indicator kesehatan karang di perairan Pulau Tunda, Kabupaten Serang, Banten. J Ilmu dan Teknologi Kelautan Tropis. 7(1):273-286.

Coral triangle initiative on coral reef fisheries security http://nccctiindonesia.kkp.go.id/?page_id=138 (diakses pada 09/03/2018). 